\title{
NIEŚMIERTELNA KSIĄŻKA ORYGENESA
}

Tak można nazwać rozprawę orygenesa "O modlitwie" ze względu na jej treść - nieprzemijającą w swej aktualności. Sławny nyśliciel, teolog, biblista, tytan pracy, rektor aleksandryjskiej szkoły katechetycznej, na prośbę swych przyjaciół z Cezarei Palestyáskiej Ambrożego i Tacjany napisał ok. 234 ŕ. wspaniałe dzieło o modlitwie i jej potrzebie ${ }^{1}$. Pragnął dać im do rąk pewne argumenty uzasadniające konieczność modlitwy w życiu chrześcijańskim i wykazujące błędne rozumowanie gnostyków, hołdujących determinizmowi i predestynacj1. Nie tylko jednak Ambroży i Tacjana, ale też i szersze grono ich przyjaciół, zaangażowanych w apostolskim życiu chrześcijańskim, otrzymali przez ten traktat znakomite wsparcie apologetyczne oraz obszerna, żywą, interesującą informację o teorii i praktyce modlitwy. Z różnorodnych aspektów orygenesowskiej koncepcji modlitwy, jak jej rodzaje, przedmiot, metoda, struiktura, podmiotowe uwarunkowania, przymioty, przeszkody, czas i miejsce oraz rola Ducha Świętego, w niniejszym artykule uwzględnimy jedynie pojecie modlitwy, jej potrzebę $i$ owoce ${ }^{2}$.

\section{POJECIE NODLITWY}

Orygenes, egzegeta $i$ autor potężnych dzieł biblijnych /"Hexapla", "Octapla", "Enneapla"/, również swojaz rozprawę "0 modlitwie" oparł na obfitym materiale Pisma św., które miał znać na pamięć $i$ pi đając ścisłą definicję moulitwy, posłużył się argumentacją biblijną Modlitwa jest - według niego - prośbą skierowaną do Boga ${ }^{3}$.

1 PG 11, 415-562.

2 Jest to Pragment pracy magisterskiej pt. "Naukowa rozprawa "O mc dlitwie Oryirenesa" pisanej pod kierunkiem ks. doc.W. Kani, Tal nów 1976 , ss. 100.

3 De oratione 4,2, PG $11,428$. 


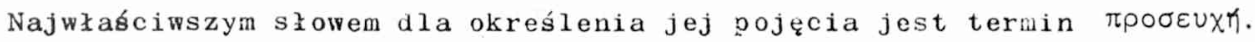
Najbliżsy tenu słowu jest termin દúxr. Jednakże słowo દúxŕ oznacza nie tyle prośbę, ile ślub. Ten pojemiejszy semanıycznie termin występuje w znaczeniu różnym $i$ zamiennym, raz jako ślub, innym razem

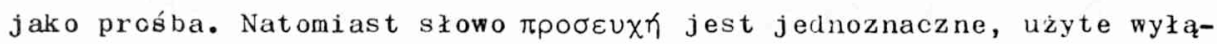
cznie jalko prośba. Księgi natchnione dostarczyły orygenesowi wielu przykładów dla potwierdzenia onomastyeznych rozróżnień.

I tak dla zilustrowania terminu $\varepsilon \dot{\chi x y}$ w znaczeniu prośby przytacza on następujące przykłady biblijne: "Ubłagajcie ( $\varepsilon \cup \dot{\xi} \alpha \sigma \theta \varepsilon$ ) Pana, aby oddalił żaby" $/ W_{j} 8,4 /^{4}$; "Błagajcie Pana, aby ustał grzmot potężny 1 grad" $/ W_{j} 9,28 / 5 ; " / \ldots /$ błagajcie Boga waszego, Pana, by usunazł ode mnie przynajmniej tę śnierć" $/ \mathbb{W j}_{10}, 17 / 6$.

Częściej słowo Eủxŕoznacza ślubowanie, złożenie ślubu, uczy-

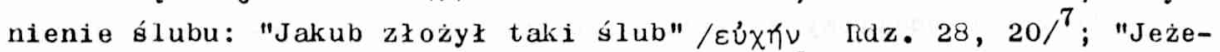
$1 i$ kto chce się uiścié ze ślubu" $/ \mathrm{Kpł} 27,2 / 8 ; 1 / \ldots /$ gdy jaki mężczyzna lub kobieta złoty ślub nazireatu" $/$ Lb $6,3 / 9$. Autor powołuje się równiés na Nowy Testament, gdzie termin "ślubowanie", "złożenie ślubu" występuje w liczbie mnogiej: "Mamy tu czterech mężczyzn, którzy

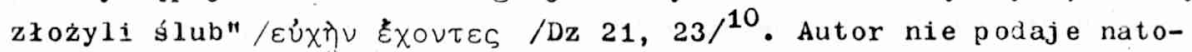

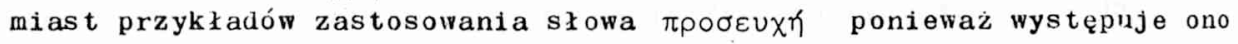
wszędzie w sensie prośby, tam gdzie jest mowa o modlitwie. Przykła-

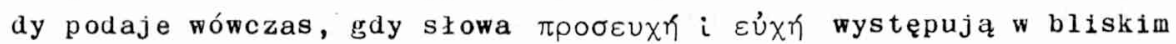
sąsiedztwie $i$ w tych samych okolicznościach, ale w znaczeniu najbardziej właściwym dla każdego z nich: rpoбeuxர jako prośba, modlitwa oraz Eủxŕ jako ślub. Oto przykład podany przez autora: "Ona zaś /Anna/ smutna na duszy zanosiła modlitwy ( $\pi \rho \circ \sigma \varepsilon u ́ \xi \alpha \tau o)$ do Boga i pła-

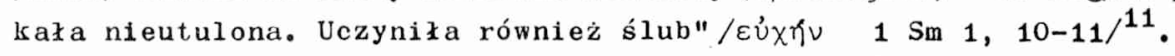

De oratione $3,2, P G 11,424 \mathrm{C}$. Tamże, 3, 3, PG 11, $425 \mathrm{~A}$.

Tamże, $425 \mathrm{~B}$.

Tamże, 3, 1, PG 11, 424 B.

Tanże, 3, 4, PG 11, $425 \mathrm{C}$.

Tamże.

10 Tanże 3, 4, PG 11, 428 A.

11 Tamże, 4, 1, PG 11, 428 B. 
Orygenes określa té̇ modlitwę jako pobożną rozmowę z Bogiem. Stwierdza na przykład, że ten, kto się modli "skupi się do modlitwy, a już samaz postawą swoją zaznaczy, że stoi przed Bogiem $\mathbf{i}$ z $\mathbf{i}$ r o z m a wi a, zdając sobie sprawę, iż Bóg go widzi oraz słyszy"12. Nie poddaje tego określenia gruntownemu rozstrząsaniu filologicznemu i analizie porównawczo-etymologicznej, jak czyni to przy definicji modlitwy jako prośby, jednakże kontekst wystarczająco wskazuje, iź autor określa modlitwę jako rozmowe z Bogiem; rozmowę niezwyczajną, lecz pełną świadomości: z Kim się rozmawia, jak sie rozmawia $i$ jak należy rozmawiać. W dalszym dowodzeniu autor dodaje też, o czym trzeba rozmawiać: "o rzeczach niebieskich"13, oraz podaje przykłady takiej pobożnej rozmowy z Bogiem: Mojżesza, Anny, Samuela, a przede wszystixim Chrystusa, rozmawiającego ze swym 0jcen Niebieskim ${ }^{14}$.

Orygenes pojmuje modlitwę również jako wzniesienie duszy do Boga, cytując na uzasadnienic tego, slowa Psalmu: "iru Tobie, Panie, wznoszę swą duszę /Ps $25,1 /^{15}$. Wyjaśniając to zdanie posuwa sie jednak do przesadnego $i$ błędnego twierdzenia:

"A gdy dusza wznosi się, idzie za Duchem $i$ o d d z 1 e 1 a sie nd ciała. Nie tylko idzie za Duchem, lecz też najściślej z Nim się jednoczy"16.

Jeśli się przyjmie sens mistyczny i moralny tego zdania, można zgodzić się z jego treścia. Prawdopodobnie jednak autor wyraził te myśl w sensie ontologicznym, uznając pewnego rodzaju wędrówkę duszy. Myśl tę zdaje się jednak korygować, gdy w końcowej części traktatu stwierdza, iż do owego ścisłego zjednoczenia z Bogiem zdolny jest tylko "sprawiedliwy, który dniem i noca $r$ o z m y ś 1 a nad Prawem Pańskim" /Ps 1, 2/17.

Aby potwierdzić swe pojęcie modlitwy, jako wzniesienia duszy do Boga, autor przytacza również słowa św. Pawła: "Będę się modlił d u c h e m, ale będę się też modlił i u m y s ł e m, będę

12 De oratione 8, 2, PG 11, $441 \mathrm{C}$.

13 Tamże, 14, 1, PG 11, $460 \mathrm{~B}$.

14 Tamże, 13, 1-2, PG 11, 453.

15 Tamże, 9, 2, PG 11, $444 \mathrm{C}$.

16 Tamże.

17 Tamże, 29, 9, PG 11, 533. 
śpiewał duchem, będę też śpiewał 1 umysłem" $/ 1$ Kor $14,15 / 18$. Powołuje się następnie na przykład Anny z I Księgi Samuela: "Gdy tak żarliwie modliła sie przed obliczem Pana, Heli przyglądał się jej ustom. Anna zaś mówiła tylkow g e b $i$ s e r c a swego. Poruszała wargami, lecz głosu nie było słychać" /1 Sm $1,12-13 / 19$. W tym samym celu Orygenes cytował słowa Psalmu: "Strapiony wylewa swą duszę przed Panem" /Ps 102, 1/20, dodając, że tego rodzaju modlitwy są "prawdziwie duchowe", poniewaz "powstały i wypowiedziane były prawdziwie w Duchu", nie są krępowane 1 ograniczone formą słowa, ale "są pełne nauk mądrośc1 Bożej" $/ 0 \mathrm{z} 14,10 /^{21}$.

Zdefiniowanie modlitwy jako prośby skierowanej do Boga oraz uzasadnienie tej definicji zgodnie z wymogami ówczesnych kryteriów lingwistycznych i hermeneutycznych jest już pewnym wskaźnikiem, pozwalającym wnosjé o naukowym charakterze Orygenesowego traktatu "0 modlitwie". Nadto, określenie modlitwy jako pobożnej rozmowy z Bogiem 1 jako wzniesienia duszy do Boga, świadczy, że jego autor jako pierwszy starał się ją ukazać dogłębnie 1 wszechstronnie. Koncepcja ta wypływa z klimatu biblijnego, w którym jej autor żył 1 tworzył dzieła o nieprzemijającej wartośc1. Dlatego też jest ona bliska ewangelicznemu duchowi siedmiu próśb Modlitwy Pańskiej.

\section{POTRZEBA MODLITWY}

Błędne założenia doktrynalne, przyjmujące zbędność, a nawet bezcelowość modlitwy, spotykamy nie tylko współcześnie, zwłaszcza u ludzi obojętnych religijnie, ale istniały równiéz w czasach orygenesa. Do problemów żywo dyskutowanych należało wówczas zagadnienie potrzeby $i$ konieczności modlitwy wobec ddwiecznych i niezmiennych planów Boga, Jego wszechwiedzy i Opatrzności. Zarzuty pochodziły nie tylko ze strony potężnego wciąż jeszcze pogaństwa, ale rów-

18 De oratione $2,4, P G 11,421 \mathrm{~A}$.

19 Tamże, 2, 5, PG 11, 424 A.

20 Tamże.

21 Tamże. 
nież ze strony tych, którzy odeszli od ortodoksyjnej nauki Kościoła, zwłaszcza od różnych odcieni gnostyków. Orygenes wymienia po imieniu, jednego z nich - Tacjana, zwanego Syryjczykiem:

\footnotetext{
"uważałem za konieczne przypomnieć fałszywe interpretacje Tacjana ludziom, których on uwiódł i którzy tę bezbożną naukę przyjęli, a których i my kiedyś znaliśmy" 22 .
}

Spośród tych ludzi rekrutowali się racjonaliści i determiniśc1 tamtych czasów, jakby prekursorzy zwolenników nauki o bezwzględnej predestynacji. Pytań dotyczących tych kwestii, wraz z zarzutami przeciwników, dostarczył orygenesowi jego niezawodny 1 wspaniałomyślny protektor Ambroży, prosząc o wyjaśnienie prawowiernej nauki 1 obalenie błędów:
"zajmiemy się wywodami tych, którzy uważają modlitwę za zbyteczną /.../. Nie zamierzamy zajmować się atei- stami, którzy odrzucają istnienie Boga, albo przeczą Jego Opatrzności, ale tymi, którzy usiłują przekonać innych, ze modlitwa jest niepotrzebna, powołując się przy tym na Pismo św."23.

A oto w streszczeniu wywody i zarzuty przeciw potrzebie oraz koniecznośc1 modlitwy, wysuwane przez gnostyckich predestynacjan: Bóg - dowodzą - wie wszystko zanim się coś stało. Po co więc kierować do Niego modlitwy, skoro juz przed modlitwami wie, co nam jest potrzebne, bo i Pismo św. to potwierdza: "wie ojciec wasz Niebieski, czego wam potrzeba, nim Go poprosicie" $/ \mathrm{Mt} 6,8 /{ }^{24}$. Bóg winien sam, bez prośby, udzielić każdemu czegio potrzeba, tak jak ojciec, który nie czeka na prośby dzieci, ponieważ moga jeszcze nie umieć mówić oraz prosić, względnie prosić o rzeczy dla nich szkodliwe. Bóg udziela więc każdemu to, czego potrzeba bez modlitwy, bo "miłuje wszystkie stworzenia" Mar 11, 24/. Bóg nie zmieni swej woli i nic nie uczyni wbrew swoim, raz powziętym postanowieniom, poniewaz nieodwołalnie

22 De oratione 24, 5, PG 11, $496 \mathrm{~B}$.

23 Tanże, 5, 1-2, $\mathrm{PG} 11,429 \mathrm{~A}$.

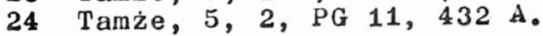


postanowił działać w przyszłości, którą zna, według nieodwołalnych planów. Żadna więc modlitwa nie noże zmienić woli Boga, tak jak nierozumny byłby ten, kto by sie modlił, aby wzeszło słońce, bo 1 bez moditwy to się stanie. Modlitwa nie ma tez wpływu na sprawę zbawienia $i$ potępienia wiecznego, bo człowiek jest dobry lub zły "niezależnie od uczynków, ale od Tego, który daje powołanie" $/ \mathrm{Rz} 9,11 / 25$. Daremna jest modlitwa o odpuszczenie grzechów, skoro "od łona matk 1 występni zeszli na bezdroża" /Ps 58,4/, a "sprawiedliwych od łona matki powołał" /Ga 1,15/ i "wybrał przed załoźeniem świata, aby byli święci i nieskalani przed Jego obliczem. Z miłości p r z e z n a c z y $\mathbf{z}$ ich ala siebie"/Ef 1, 4/, a "których p r z e z n a c z y $\mathbf{x}$, tych tez powołał /.../, tych też obdarzył chwałą" /Rz 8, 29-30/. Jak Ezaw był odrzucony, tak Jakub wybrany już przed urodzeniem / $\mathrm{Rdz} 25,23$; Ml 1, 3/. Podobnie i Judasz został odrzucony już w przepowiedni Dawida /Ps $109,8 / 26$.

W polemice z'tymi błędami 1 zarzutami orygenes okazuje sie zna-. komitym uczonym, biegłym filozofem 1 wielkim teologiem. W oparciu o ówczesny stan wiedzy teologicznej i filozoficznej, dowodzi on istnienia wolnej woli rozumnej istoty ludzkiej, która sama od siebie wydaje sądy, podejmuje decyzje, wyraża zgodę lub sprzeciw i wybiera czynności:

"Kto zwróci ứragę na swą świadomość, niech stwierdzi, czy może spokojnie powiedzieć, że nie sam chce, nie sam spozywa pokarm, nie sam chodzi, nie sam wydaje sądy i wyraza zgodę, nie sam odrzuca to, co fałszywe?"27

Wolnej woli ludzkiej dowodzi stosowanie kary za złe czyny, a nagrody za dobre czyny. W przeciwnym razie niedorzecznym byłoby karać przestępce, skoro jest niewinny, bo musiał źle czynić; oraz nagradzać 1 pochwalać dobre czyny, skoro musiał je spełniać człowiek cnotliøy. Wolna wola skłania człowieka zarówno do cnoty, jak $i$ do występków, do wypełnienia obowiązków, lub ich zaniedbania.

"Prawda wywiera siłe i zmusza - choćby kto wysunał niezliczone kontrargumenty - do chwalenia lub

25 De oratione $5,4, \mathrm{PG} 11,432 \mathrm{C}$.

26 Tamże, 5, 5, PG 11, 432 D - 433 A.

27 Tamże, 6, 2, PG 11, 436 B. 
nagany, gdy się widzi wo 1 n ą w o l ę, która niezaleznie od nas zasługuje na pochwałę lub naganę"28.

Jako istota rozumna $i$ obdarzona wolną wolaz, jest człowiek odpowiedzialny za swe czyny i według nich jest sprawiedliwie sądzony przez Boga. Boża wszechwiedza odnosząca się również do przyszłośc1, w niczym nie wpływa na wolną decyzję woli ludzkiej. Bóg zna wolę każdego i naprzód w swej sprawiedliwości i Opatrzności określił, co przysługuje każdemu według jego czynów. Uwzględnił też modlitwe człowieka, o co człowiek będzie prosił, w jakim usposobieniu będzie sie modlił oraz - czy ta modlitwa będzie wysłuchana i w jakim stopniu: "proszącemu udzielę tego, czy tantego, a nawet uczynię więcej niż prosi i zdoła pomyśleć" / Ef $3,20 / 29$.

Modlącenu się Bóg przysyła do pomocy anioła. Ale gdy człowiek osłabnie w modlitwie, wróci do rzeczy światowych, utraci towarzystwo i pomoc anioła, wówczas do lekkomyślności dołączy się szatan i będzie skłaniał człowieka do grzecinu; jeśli zaś mu człowiek ulegnie, wtedy ukocha zło i już nie będzie chciał dobra. Tak stało się z Judaszem, który początkowo był szlachetny i dobry, ale stał się przewrotny z własnej woli, bo nikt go nie zmuszał do zdrady Mistrza. Bóg przewidział czyn Judasza, ale to przewidzenie w niczym nie krępowało wolnej woli zdrajcy, który działał z wolnej decyzji własnej. Bóg wiedział również od początku, że Paweł będzie prześladował Kościół, ale też przewidział jego nawrócenie $i$ to, że z pokoraz wyzna: "z łaski Bożej jestem tym kim jestem, a dana mi łaska Jego, nie okazała się daremną; przeciwnie, p $r$ a o w a $ł$ e m więcej od nich" $/ 1$ Kor $15,10 / 30$.

Tak więc bez współpracy z łaskį, która wyraża się w modlitwie, nie można wytrwać w cnocie $i$ w pełnieniu dobrych czynów. Czy można tedy zaniechać modlitwę? Nawet słońce, księzyc i gwiazdy - jakby się modliły i wielbiły Bora, głosząc Jego chwałę, potęgę, wszechmoc i wieczność - już samym swoim istnieniem: "Chwalcie Boga słońce 1 księżycu, chwalcie Go wszystkie gwiazdy świecące" /Ps $148,3 / 31$.

28 De oratione $436 \mathrm{C}$.

29 Tanże, 6, 4, PG 11, 437 B.

30 Tanze, 6, 5, PG 11, $437 \mathrm{D}-440$ B.

31 Taiż̇e, 7, 1, PG 11, $440 \mathrm{C}$. 
Nie mają więc racji ci, którzy przewrotnie tłumacząc Pismo św., usiłują mó́wić innym, że modlitwa nie ma sensu, że jest zgoła niepotrzebna. Przeciwnie: Pismo św. w całości zachęca do modlitwy, dzięki której patriarchowie, Mojżesz, sędziowie, prorocy, święci mężowie, pobożne niewiasty 1 królowie, oraz naród wybrany Starego Przymierza dostąpił niepojętych i niezliczonych dobrodziejstw Bożych ${ }^{32}$. Co wiecej - sam nasz Pan, Syn Boży, Arcykapłan i Pośrednik Nowego Przymierza wprost nakazał się modlić oraz nauczył nas najpiękniejszej modlitwy i sam u ojca modli się za nodlących sią, błaga za błagającymi Go. Nie będzie jednak modlił się jak za przyjaciół za tych, którzy się nie modlą, "ani nie będzie opiekunem przed ojcem tych, którzy nie słuchają Jego poleceń, by zawsze się modlić"33.

\section{OWOCE MODLITWX}

"Kto należcie się modli /.../ ten osiagnie wiele dobrego"34. To ogólne stwierdzenie popiera autor szerszą prezentacja błogosławionych skutiów dobrej modlitwy.

Już przez samo przysposobienie się do modlitwy, a więc: skupienie, pełną godności postawę zewnętrzną, zaznaczającą trwanie w Bożej obecności, modlący się odnosi niemałą korzyść. Pamięć na obecność Boża w czasie modlitwy odwodzi od wielu grzechów, a prowadzi do lieznych cnót. Jeżeli pamię́ o sławnym i mądrym człowieku pomaga w dobrym postępowaniu i osłabia złe skłonności, to niewspółmiernie więcej korzyści przynosi myśl o Bogu, najlepszym ojcu, który patrzy na nas, który nas kocha ${ }^{35}$.

Modlitwa pozwala jakby "z odsłoniętą twarzą wpatrywać się w jasność Pańska /.../, jrzemieniając modlącego się w Boże wyobrażenie, z jasności w jasność /2 Kor 3, 18/. Prowadzi do uczestniczenia w pewnego rodzaju "wypływie Boga", według słów Psalmu: "Widoczna

32 De oratione 14, PG 11, 460-464.

33 Tamże, 10, 2, PG 11, 445 D.

34 Tamże, 8, 2, PG 11, 441 B.

35 Tauże, $441 \mathrm{C}$ D. 
jest nad nami światłość Twego oblicza"/Ps 4, 7/. Modlitwa prowadzi do uduchowienia człowieka. Pozwala nam bowiem jednoczyć się z Bogiem: "Ku Tobie Panie wznoszę swą duszę" /Ps $25,1 / 36$.

Modlący się z czystym sumieniem ma udział w obcowaniu Swiętych. Uczestniczy bowiem w modlitwie samego Chrystusa, który ustawicznie mstawia się za nami do jjca w niebie /Hebr 2, 17; J 14, 16/37 oraz w modlitwach całcgo Kościoła, Aniołów, Swiętych i wszystkich dusz wiernych zmarłych, bo "trzeba przyjąć, że oni więcej niż my modlą się za nami, prosząc skuteczniej od nas" $/ 2 \operatorname{Mch} 15,13 / 38$.

Modlitwa pomaga w wypełnieniu największego przykazania Zbawiciela, tj. miłości Boga i bliźniego. Rozwija miłość bliźniego, gdy modlimy się za cierpiących, udręczonych, a zwłaszcza, gdy przebaczamy i zapominamy o krzywdach doznanych od bliźnich ${ }^{39}$.

Przez gorliwą modlitwę chrześcijanin przyczynia się do jednoczenia tych, którzy sa w rozproszeniu; uprasza wiele łaski zbawiennej dla tycil, którzy boją się Boga i wzywają Go. Pomaga Kościołowi w spełnieniu jego zbawczej misji, przyczynia się do rozwoju Królestwa Bożego 40 .

Usilna.modlitwa $z$ pokornym błaganien wyjednała nawrócenie wielu. Niesprawiedliwi stali się sprawiedliwymi, a niewstrzemięzliwi opanowanymi i cnotliwymi 41 .

Dzieje patriarchów, proroków, królów 1 pobożnych niewiast świadczą przekonywująco, jak wiele dobrodziejstw i niezliczonych błogosławieństw sprowadziła ufna modiitwa, zanoszona przez nich z żarliwością serca do ojca wszechrzeczy ${ }^{42}$. Każdy może wyliczyć wiele dobrodziejstw otrzymanych od Boga, gdy modlił się z czystyra sumieniem. Chodzi o dary wyższego rzędu, duchowe, choć Bóg dodaje według własnej woli $i$ upodobania, równieź dobra znikome, tj. doczesne ${ }^{43}$.

Wielu dostąpiło zbawienia dzięki nodlitwie, która pomogła im "przez ducha poddać umartwieniu popędy ciała" /Rz 8, 13/. Mogli też dzięki niej przezwycieżyć pokusy złośliwych duchów. Nawet ci, którzy

36 De oratione $9,2, \mathrm{PG} 11,444 \mathrm{C}$.

37 Tamże, 10, 2, PG 11, $445 \mathrm{C} \mathrm{D}$.

38 Tanże, 11, 1-4, PG 11, $448 \mathrm{~B}-449 \mathrm{C}$.

39 Tamże, 9, 1-3, PG 11, 444 A D.

40 Tanże, 11, 3, PG 11, $449 \mathrm{C}$.

41 Tamże, 26, 6, PG 11, 504 C.

42 Tamże, 13, 2-5, PG 11, $453 \mathrm{C}-456 \mathrm{C}$.

43 Tamże, 17, 1, PG 11, 472 A. 
ulegli grzechom, zostali wyrwani od potępienia, dzięki pokucie, błaganion $i$ modlitwom, "jeżeli nie zwątpili w możliwość zbawienia". Co więcej - mogli później sami pomagać innym do zbawienia ${ }^{44}$.

Modlitwa urocniła w życiu duchowym tych, którzy tęsknili za Bogiem. Pan zamieszkał i pomnozył swe skarby łask w ich duszy ${ }^{45}$.

Wytrwała i żarliwa modlitwa prowadzi do wewnętrznej przemiany, do "odnowienia umysłu" /Rz 12, 2/. "Sprawy diabła" zostaja zniszczone, gdy przez siłę i nadprzyrodzoną moc modlitwy wchodizi do naszej duszy Słowo Boże, Syn, będący wiekuistym odbiciem ojca Niebieskiego, aby was sprawić "odbicie i obraz człowieka niebieskiego" / $1 \mathrm{~J} 3$, $8 / 46$

Modlitwą gotujemy drogę ku temu, co jest doskonałe, aby Króles,two Boże osiagnęło w nas swój szczyt. Niemożliwe jest współistnienie Królestwa Laski i światła Bożego wraz z królestwem grzechu i ciemności szatana u tego, kto całym sercen oddaje się nodlitwie, a nie uczynkom ciała $a^{47}$. Bowiem dobra modlitwa przynosi zawsze "owoce ducha", a kto "oddaje się Panu, staje się z Nim jednym duchem"/1 Kor $6,17 / 48$

Modlący się wytrwale i z ufnościa, umieścił już serce w niebie, dlatego tez skarby swoje gromadzi w niebie. Ciałem przebywa jeszcze na ziemi, ale duchem należy już do świata niebieskiego $i$ nosi w sobie podobieństwo "człowieka niebieskiego" /1 Kor 15, 49/. Człowiek bez rodlitwy jest "ziemią i stanie się ziemią, jeśli się nie nawróci". Natomiast wierny, gdy wypełnia Przykazania Boga, gdy wytrwale modli się o to: "Bądź Wola Twoja" - wówczas jest "niebem"49".

Przez modlitwę otrzymany więcej niż to, o co prosimy Boga, lub co możemy objąć umysłem, bo otrzymamy to, "czego oko nie widziało, ucho nie słyszało $i$ serce człowieka nie zdołało pojác" / 1 Kor 2 , $9 /$, a nawet więcej jeszcze, ponieważ nie możemy tego objąć myślą ${ }^{50}$. Bóg może nam udzielić tych dóbr niebieskich, jest bowiem wszechmocny oraz udzieli ich nam na podstawie swojej wierności 1 obietnicy Chrystusa: "O cokolwiek byście prosili ojca mego w imię moje da wam. Aż

44 De oratione 13, 4, PG 11, 456 D - 457 A.

45 Tamże, 20,2, PG 11, $480 \mathrm{C}$.

46 Tamże, 22, 4, PG 11, 485 B C.

47 Tanze, 25, 2-3, PG 11, $496 \mathrm{C}-497 \mathrm{~B}$.

48 Tamże, 26, 3, PG 11, 501 A.

49 Tamże, 26, 5-6, PG 11, 504 A C.

50 Tamże, 27, 15, PG 11, $520 \mathrm{C}$. 
do tej pory o nic nie prosiliście w imię moje. Proście a otrzymacie, aby radość rasza była pełna" $/ J 16,23 /{ }^{51}$.

Modlitwa przechyla szalę zwycięstwa nad słabościami, gnuśnościa i pokusami, pomaga znosić cierpienia: "zewsząd znosimy cierpienia, lecz nie poddajemy sie zwatpieniu" /2 Kor 4, 8/. Daje też radość wewnętrzną i pokój duszy, którym nas obdarza w chwilach nieszczęść Bóg Miłosierny ${ }^{52}$.

Modlitwa daje prawdziwe zadowolenie serca. oto przez ufne i dziecięce zawierzenie opatrzności, przez oddalenie wszystkich trosk o sprawy doczesne, uwalnia nas ona od niepokoju i dręczących myśli. "Czyż nie będzie to stan szczęśliwy?"53

Autor, wielki asceta, nazywa prawdziwie błogosławionymi tych wszystkich, którzy w gorliwej $i$ wytrwałej modlitwie będą wznosić do Boga czyste ręce, "bez gniewu i sporu" /1 Tm 2, 8/. Tacy chrześcijanie będą postępować skromnie i obyczajnie, a ich dusze będą zdobiły najpiękniejsze owoce dobrych czynów ${ }^{54}$.'

Przegląd treści trzech omówionych kwesti1 - spośród szeregu innych - poruszonych w rozprawie Orygenesa, wskazuje, że znakomity autor wywarł znaczny wpływ na kształtowanie duchowości 1 ascetyk 1 Kościoła. W ciągu wieków powstała obszerna literatura religijna, poświęcona sprawom modlitwy, bo przeciez cała historia zbawienia pozostaje pod znakiem modlitwy; jest ona wyrazem ostatecznych $i$ wiecznych dążeń człowieka, jest koniecznym współdziałaniem ze Stwórcą w udoskonaleniu i zbawieniu człowieka. Dzleło Orygenesa "O modlitwie" zawiera wszystkie merytoryczne elementy teorii i praktyki modiftwy. Słusznie więc można powiedzieć, że jego rozprawa "0 modlitwie" jest "Książką nieśmiertel ną".

\section{Ks. Zbigniew Ćwik - Tarnów}

\section{DE IMMORTALI OIIGENIS LIBRO /Argumentum/}

Ab amicis suis Ambrosio et Tatiana rogatus Origenes anno 234 in Caesarea Palaestinensi opus "De oratione" scripsit. Quae res in Chri-

51 De oratione 15, 2, PG 11, $465 \mathrm{C}$.

52 Tamże, 12, 1; 13, 2; 9, 1; 30, 1, PG 11, $452 \mathrm{~B} \mathrm{C,} 453 \mathrm{C}, 444 \mathrm{~A}$, $545 \mathrm{C}$.

53 Tanże, 9, 1, PG 11, 444 A.

54 Tamże. 
stianorum litteris primum orationis problema omni ex parte et modo scientifico explicavit, id est orationis genera, elusque obiectum, structuram et methodum, proprietates, conditiones ac difficultates. Ilac in dissertantiuncula explicantur Origenianus conceptus, necessitas necnon fructus orationis, quae ad virtutes ducit, a peccatis avertit et cum Deo iungit. 